\title{
Studi Putusan Hakim Nomor: 29/Pid.Sus/TPK/2018/PN.Jmb terhadap Pelaku Tindak Pidana Korupsi Pembangunan Embung di Desa Sungai Abang Kecamatan VII Koto Kabupaten Tebo Tahun 2015
}

\author{
Muhammad Badri ${ }^{*}$, Bambang Harianto ${ }^{2}$ \\ ${ }^{1,2}$ fakultas hukum, universitas Batanghari, \\ Jalan Slamet Riyadi Broni Kota Jambi Telp: (0741) 65351 \\ *Correspondence email: muhammadbadri1972@gmail.com
}

\begin{abstract}
Abstrak. Tindak pidana korupsi mengalami peningkatan dari waktu ke waktu, sehingga dilihat dari perkara-perkara korupsi yang ada pada saat ini.seperti pelaku non direktif baik itu dikalangan pemerintah pusat maupun pemerintahan daerah. Seperti terjadi di Kabupaten Tebo dalam pembangunan embung. Dampak paling besar dari kejahatan korupsi ini bisa menjadi hambatan dalam pembangunan disegala bidang dalam hal ini maka sangat diberikan sanksi pidana sebagai tanggung jawab bagi pelaku korupsi. Perihal penjatuhan putusan kepada pelaku korupsi, seorang hakim diwajibkan tahu dan sadar makna pemindanaan yang dijatuhkan serta tahu dan sadar apa yang ning dicapainya, tujuan penjatuhan pidana yang berat selain untuk memberikan penjeraan bagi yang melakukan tindakan yang melawan hukum, membuat masyarakat takut melakukan tindakan yang serupa juga untuk mewujudkan rasa keadilan masyarakat.
\end{abstract}

Kata Kunci: Studi Putusan; Tindak Pidana Korupsi; Pembangunan Embung

Abstract. Corruption crimes have increased from time to time, so it can be seen from the corruption cases that exist today, such as non-directive actors, both among the central government and regional governments. as happened in Tebo Regency in the construction of an embung. The biggest impact of this corruption crime can be a barrier to development in all fields, in this case, criminal sanctions are very much given as responsibility for the perpetrators of corruption. Regarding the imposition of a verdict on the perpetrator of corruption, a judge is required to know and be aware of the meaning of impeachment as well as to know and be aware of what he has accomplished, the purpose of imposing serious crimes in addition to providing deterrence for those who commit acts that are against the law, making people afraid to commit similar actions also to create a sense of community justice.

Keywords: Decision Study; Corruption Crime; Embung Development

\section{PENDAHULUAN}

Manusia yang merupakan makhluk sosial yang mengakibatkan tidak terlepas dari manusia lainnya, sehingga karena itu tidak bisa kita lepas dari masalah dalam kehidupan. Seiring berkembangnya manusia juga sejalur dengan berkembangnya masalah, hal ini menuntut hukum untuk lebih maju. Tujuannya menjaga keseimbangan antara manusia dengan peraturan-peraturan dalam pengaturan perilaku mereka, yang mana telah di amanatkan pada Undangundang Dasar 1945 yang menjelaskan Indonesia berlamdaskan hukum. Akbatnya Indonesia harus melindungi HAM dan persamaan didalam hukum. ${ }^{1}$

Dirumuskan suatu hukum guna memberi jawaban atas pelanggaran-pelanggaran terhadap norma yang ada dalam masyarakat, yaitu suatu KUHP yang selanjutnya disingkat KUHP. KUHP memberikan batasan perbuatan yang boleh ataupun tidak atau dilarang yang diatur Undang-Undang serta mengatur sanksi untuk semua orang yang tidak mentaati aturan hukum.

Manusia hidup tidak bisa lepas dengan manusia lain. Interkasi yang terjadi mengharuskan adanya suatu aturan agar kehidupan yang dijalani berjalan dengan aman dan tentram. Aturan itulah yang menimbulkan suatu hukum.konsekuensi adanya hukum, hukum harus ditegakkan yang mana harus ada suatu organisasi/badan yang menentukan suatu perbuatan manusia benar atau salah. Di Indonesia dalam hal menegakkan hukum terdapat suatu lembaga yaitu lembaga peradilan. Didalamnya terdiri aparat yang berhak menegakkan hukum.salah satu aparat tersebut ialah Hakim.

Kekuasaan yang dimiliki oleh hakim yaitu merdeka terbebas dari intervensi pemerintah, atas hal ini seorang hakim berkuasa memutusskan suatu hukum tanpa ada intervensi dari pihak manapaun.Akibatnya hal ini bisa menciptakan wewenang hakim yang merdeka.

Hakim diatur tentang kedudukannya pada Undang-undang No.48 Tahun 2019 mengenai Kekuasaan Kehakiman, seperti bahwa:

\footnotetext{
${ }^{1}$ Bambang Waluyo, Pidana dan Pemidanaan, Jakarta, Sinar Grafika, 2000, hal. 6.
} 
"Kekuasaan kehakiman menurut Undang-UndangDasar Negara Republik Indonesia Tahun 1945 merupakan kekuasaan yang merdeka yang dilakukan oleh sebuah Mahkamah Agung dan badan peradilan yang berada di bawahnya dalam lingkungan peradilanumum, lingkungan peradilan agama, lingkungan peradilan militer, lingkungan peradilan tata usahanegara, dan oleh sebuah Mahkamah Konstitusi, untuk menyelenggarakan peradilan guna menegakkan hukum dan keadilan".

Keberanian hakim dalam menegakkan hukum yang adil tanpa pandang bulu dan pamrih dituntut guna melaksanakan tugasnya sebagaimana pada Undang-undang No.48 Tahun 2009 Pasal 4 ayat (1) yang berbunyi:

"Pengadilan mempertimbangkan sesuai dengan aturan hukum tanpa membeda-bedakan orang".

Menurut Paul Scholten yang di kutib oleh Nanda Agung Dewantara, bahwa hakim tidak hanya berkutat tentang memutuskan sesuai konteks dan teks, tetapi juga memperhatikan dan mempertimbangkan integritas dan hati nurani. Hal ini berarti formatilas belaka tidak hanya dibutuhkan dalam suatu keputusan hakim tetapi juga memperhatikan moral lagi kesusialaan. ${ }^{2}$

Korupsi perlu untuk di cegah dan mengurangi tindak pidana korupsi tersebut, dimana peranan hakim tidak terlepas dalam rangka ini khususnya putusan hakim terhadap salah satu kasus. Dalam mengambil keputusan hakim harus mempertimbangkan agar asas keadilan terpenuhi. Menurut Sudarto Hakim bebas dalam menentukan pidana serta tinggi dan rendahnya suatu pidana, juga memiliki kebebasan dalam batas maksimum dan minimum sanksi pidana terhadap tindak pidana. Berarti bahwa hakim berkuasa dalam masalah pemindanaan. ${ }^{3}$ Korupsi yang bukan saja bisa mangakibatkan kerugian bagi finansial dalam Negara namun juga dapat memunculkan kehilangan dari pada ekonomi masyarakat.Arief Nawawi Barda mengatakan, korupsi dimata dunia adalah perbutan yang tercela juga hina dan terkutuk yang dibenci oleh seluruh masyarakat dunia $^{4}$

Korupsi yang bukan saja bisa mangakibatkan kerugian bagi finansial dalam Negara namun juga dapat memunculkan kehilangan dari pada ekonomi masyarakat. Arief Nawawi Barda mengatakan, korupsi dimata dunia adalah perbutan yang tercela juga hina dan terkutuk yang dibenci oleh seluruh masyarakat dunia ${ }^{5}$

Tindak pidana korupsi mengalami peningkatan dari waktu ke waktu, sehingga dilihat dari perkara-perkara korupsi yang ada pada saat ini.seperti pelaku non direktif baik itu dikalangan pemerintah pusat maupun pemerintahan daerah. Seperti terjadi di Kabupaten Tebo dalam pembangunan embung. Dampak paling besar dari kejahatan korupsi ini bisa menjadi hambatan dalam pembangunan disegala bidang dalam hal ini maka sangat diberikan sanksi pidana sebagai tanggung jawab bagi pelaku korupsi.

Peraturan yang mengatur masalah korupsi terdapat pada Undang-undang No. 20 Tahun 2001 Tentang Perubahan Atas Undang-undang No. 31 Tahun 1999 Tentang Pemberantasan Tindak Pidana Korupsi. Dalam Undangundang No. 20 Tahun 2001 Tentang Perubahan Atas Undang-undang No.31 Tahun 1999 Tentang Pemberantasan Tindak Pidana Korupsi.pidana yang dapat diberikan kepada pelanggar dapat ditambah yang ditentukan dalam Pasal 18, yang menentukan:

(1) Selain pidana tambahan sebagaimana dimaksud dalam Kitab Undang-undang Hukum Pidana, sebagai pidana tambahan adalah :

a. Perampasan barang bergerak yang berwujud atau yang tidak berwujud atau barang tidak bergerak yang digunakan untuk atau yang diperoleh dari tindak pidana korupsi, termasuk perusahaan milik terpidana dimana tindak pidana korupsi dilakukan, begitu pula harga dari barang yang menggantikan barang-barang tersebut

b. Pembayaran uang pengganti yang jumlahnya sebanyak-banyaknya sama dengan harta benda yang diperoleh dari tindak pidana korupsi

c. Penutupan seluruh atau sebagian perusahaan untuk waktu paling lama 1 (satu) tahun

d. Pencabutan seluruh atau sebagian hak-hak tertentu atau penghapusan seluruh atau sebagian keuntungan tertentu, yang telah atau dapat diberikan oleh Pemerintah kepada terpidana.

(2) Jika terpidana tidak membayar uang pengganti sebagaimana dimaksud dalam ayat (1) huruf b paling lama dalam waktu 1 (satu) bulan sesudah putusan pengadilan yang telah memperoleh kekuatan hukum tetap, maka harta bendanya dapat disita oleh Jaksa dan dilelang untuk menutupi uang pengganti tersebut.

(3) Dalam hal terpidana tidak mempunyai harta benda mencukupi untuk membayar uang pengganti sebagaimana dimaksud dalam ayat (1) huruf $b$, maka dipidana dengan pidana penjara yang lamanya tidak melebihi ancaman

2 Nanda Agung Dewantara, Masalah Kebebasan Hakim Dalam Menangani Suatu Perkara Pidana, Jakarta, Aksara Persada Indonesia, 1987, hal 35-36

${ }^{3}$ Sudarto, Kapita Selekta Hukum Pidana, Bandung, Alumni, 1986. hal.78

${ }^{4}$ Muladi dan Barda Nawawi Arief, Bunga Rampai Hukum Pidana, Bandung, Alumni, 1992, hal 133

${ }^{5}$ Muladi dan Barda Nawawi Arief, Bunga Rampai Hukum Pidana, Bandung, Alumni, 1992, hal 133 
maksimum dari pidana pokoknya sesuai dengan ketentuan dalam Undang-undang ini dan lamanya pidana tersebut sudah ditentukan dalam putusan pengadilan.

Perihal penjatuhan putusan kepada pelaku korupsi, seorang hakim diwajibkan tahu dan sadar makna pemindanaan yang dijatuhkan serta tahu dan sadar apa yang ning dicapainya. Oleh karena itu, serangkaian kebijakan kriminal pada putusan hakim jangan terlepas yang mana akanmempengaruhi tahap berikutnya ${ }^{6}$

Sebagaimana diketahui bahwa tujuan penjatuhan pidana yang berat selain untuk memberikan penjeraan bagi yang melakukan tindakan yang melawan hukum, membuat masyarakat takut melakukan tindakan yang serupa juga untuk mewujudkan rasa keadilan masyarakat. Namun dalam kenyataannya, pidana yang dapat diberikan masih tergolong ringan, diantaranya yang terjadi di wilayah hukum Pengadilan Negeri Jambi, dengan perkara Nomor: 29/Pid.Sus/TPK/2018/PN.Jmb. hakim dalam memberikan putusan denngan menetapkan penjara 2 tahun penjara dengan denda Rp. 50.000 .000 (tambah kurungan 3 bulan bila tidak di bayar) dan uang sebagai pengganti akan kerugian Negara Rp. Rp. 353.338.415,41 (diganti kurungan 1 tahun bila tidak di bayar 1 bulan sejak putusan hakim), putusan terkait denda dan uang sebagai pengganti akan kerugian Negara nilainya sama besar dengan yang di jatuhkan kepada terdakwa an. Faisal Utama, yang notabene terdakwa Faisal Utama hanya merupakan boneka dan suruhan dari terdakwa Ir. Jonaita Nasir Als Jonet dan hanya menerima uang gaji bulanan, sedangkan terdakwa Ir. Jonaita Nasir Als Jonet adalah sebagai darder (otak pelaku) yang bertindak selaku pengendali setiap item kegiatan baik teknis maupun non teknis dan keuangan proyek tersebut, dan yang bermanufer dengan kadis pertanian (teman kuliahnya di UNJA) dan menikmati uang hasil proyek.

Dengan adanya permasalahan tersebut maka sudah seharusnya dilakukan penegakan hukum secara tegas terhadap pelaku tindak pidana korupsi pembangunan embung di desa sungai abang kecamatan vii koto kabupaten tebo. Untuk itu, penulis memberikan batasan terkait dengan permasalahan yang akan di bahas dalam penelitian ini. Adapun batasan masalah terkait dengan permasalan di atas yaitu:

1 Apakah Putusan Hakim N0 29/Pid.Sus-Tpk/2018/Pn.Jmb terhadap pelaku tindak pidana korupsi Pembangunan Embung Di Desa Sungai Abang Kecamatan VII Koto Kabupaten Tebo Tahun 2015 telah memenuhi keadilan?

2 Apakah yang menjadi dasar pertimbangan hukum hakim terhadap ringannya putusan dalam menjatuhkan pidana bagi pelaku Tindak Pidana Korupsi Pembangunan Embung Di Desa Sungai Abang Kecamatan VII Koto Kabupaten Tebo Tahun 2015 perkara N0 29/Pid.Sus-Tpk/2018/Pn.Jmb?

\section{METODE}

Dalam suatu penelitian, apapun jenis penelitian, pasti memerlukan dan menggunakan suatu cara atau metode agar penelitian yang sedang dikerjakan dapat selesai dan membuahkan hasil sebagaimana tujuan awal yang ingin dicapai. Oleh karena itu, dibawah ini metode penelitian yang digunakan dalam penelitian ini yaitu:

\section{Metode pendekatan}

Sebelum penulis menjelaskan terkait dengan metode pendekatan dalam penelitian ini, terlebih dahulu penulis akan memberitahukan bahwa tipe penelitian dalam penelitian ini yaitu deskriptif analitis. Suatu penelitian deskriptif dimaksudkan untuk memberikan data yang seteliti mungkin tentang manusia, keadaan atau segala-segala lainnya. ${ }^{7}$ Dalam penelitian ini akan digambarkan tentang Putusan Hakim N0 29/Pid.Sus-Tpk/2018/Pn.Jmb terhadap pelaku tindak pidana korupsi Pembangunan Embung Di Desa Sungai Abang Kecamatan VII Koto Kabupaten Tebo Tahun 2015

Pendekatan pada penelitian ini menggunakan pendekatan yuridis normatif, yaitu pendekatan yang menggunakan konsepsi legis positivis. Yaitu suatu Konsep yang memandang hukum itu sama persis dengan norma-norma yang tertulis dan dibuat serta diundangkan atas pejabat maupun lembaga yang memiliki wewenang. Selain itu konsepsi tersebut memandang hukum dari sistem yang normatif bersifat otonom, yaitu terlepas dari kehidupan masyarakat ${ }^{8}$

\section{Rancangan kegiatan}

Di dalam penelitian hukum deskriptif analitis ini dilakukan rancangan kegiatan agar mendapat hasil yang diteliti sesuai dengan yang diharapkan. Rancangan kegiatan ini dilakukan guna untuk mempercepat dan mempermudah penulis dalam melakukan penelusuran terkait dengan kasus tindak pidana Korupsi Pembangunan Embung Di Desa Sungai Abang Kecamatan VII Koto Kabupaten Tebo Tahun 2015.

Untuk itu, apabila dilihat dalam penelitian ini yang mana menggunakan pendekatan yuridis normative, maka rancangan kegiatan yang dilakukan di dalam penelitian ini adalah langsung menganalisis Putusan Hakim N0

\footnotetext{
${ }^{6}$ Ibid. hal 100.

${ }^{7}$ Soerjono Soekanto, Pengantar Penelitian Hukum, UI Press, Jakarta, 1981, hal. 10.

${ }^{8}$ Ronny Hanitijo, Metodologi Penelitian Hukum, Ghalia Indonesia, Jakarta, 1983, hal.11
} 
Muhammad Badri dan Bambang Harianto, Studi Putusan Hakim Nomor: 29/Pid.Sus/TPK/2018/PN.Jmb terhadap Pelaku Tindak Pidana Korupsi Pembangunan Embung di Desa Sungai Abang Kecamatan VII Koto Kabupaten Tebo Tahun 2015

29/Pid.Sus-Tpk/2018/Pn.Jmb atas kasus tindak pidana Korupsi Pembangunan Embung Di Desa Sungai Abang Kecamatan VII Koto Kabupaten Tebo Tahun 2015

\section{Ruang lingkup atau objek}

Diadakan ruang lingkup dalam penelitian ini bertujuan agar ada batasan yang dikaji di dalam penelitian ini sehingga memfokuskan bagi peneliti untuk meneliti permasalahan yang sedang diteliti dan mempermudah bagi pembaca untuk memahami permasalahan yang sedang diteliti oleh peneliti. Adapun ruang lingkup di dalam penelitian ini adalah Putusan Hakim N0 29/Pid.Sus-Tpk/2018/Pn.Jmb atas kasus tindak pidana Korupsi Pembangunan Embung Di Desa Sungai Abang Kecamatan VII Koto Kabupaten Tebo Tahun 2015

\section{Bahan dan alat utama}

Bahan yang dimaksudkan dalam penelitian ini adalah bahan yang akan digunakan untuk mengkaji permasalahan yang sedang diangkat yaitu permasalahan tentang tindak pidana Korupsi Pembangunan Embung Di Desa Sungai Abang Kecamatan VII Koto Kabupaten Tebo Tahun 2015. Adapun bahan yang digunakan di dalam penelitian ini adalah data primer. Data primer yakni data yang diperoleh sumbernya langsung dari lapangan yaitu Putusan Hakim N0 29/Pid.Sus-Tpk/2018/Pn.Jmb.

\section{Teknik pengumpulan data}

Oleh karena penelitian ini merupakan penelitian hukum normatif, maka Sumber data pada penelitian ini yang di gunakan penulis menggunakan sumber data kepustakaan:

1. Bahan Hukum primer yaitu dengan meneliti putusan hakim yang berkaitan dengan penulisan skripsi ini yaitu putusan Hakim N0 29/Pid.Sus-Tpk/2018/Pn.Jmb

2. Bahan Hukum sekunder yang berupa buku-buku atau literatur-literatur yang berkaitan dengan dengan penulisan skripsi ini.

3. Bahan Hukum Tertier yaitu KBBI dan Kamus Hukum.

\section{Teknik analisis}

Seluruh data yang diperoleh baik data lapangan maupun data kepustakaan selanjutnya dianalisis secara kualitatif yaitu dengan menafsirkan dan menuturkan atas data yang bersangkutan yang dengan situasi terjadi, juga sikap serta pandangan didalam masyarakat. Seperti putusan Hakim N0 29/Pid.Sus-Tpk/2018/Pn.Jmb

\section{HASIL DAN PEMBAHASAN}

Apakah Putusan Hakim No 29/Pid.Sus-Tpk/2018/Pn.Jmb terhadap pelaku tindak pidana korupsi Pembangunan Embung Di Desa Sungai Abang Kecamatan VII Koto Kabupaten Tebo Tahun 2015 telah memenuhi keadilan

Mendapatkan keadilan serta kepastian hukum oleh hakim dalam setiap keputusannya sangatlah susah, karena Indonesia tidak mengenal"dissenting opinion" , juga melakukan akses yang terbuka atas hasil bahan pemutusan hakim, lebih lagi dengan kaitannya prosfesianolisme hakim atas penguasaan dari hukum (rechtsvinding) dan integritas moral hakim dalam memutuskan hukum yang adil.

Suatu keputusan seorang hakim memiliki kualitas yang berbeda antar satu keputusan hakim yang satu dengan keputusan hakim yang lain. Perbedaan kualitas putusan hakim ini disebabkan oleh banyak hak atau banyak faktor, salah satu faktor yang mempengaruhi kualitas putusan hakim adalah tingkat pendidikan seorang hakim. Tingkat pendidikan hakim mempengaruhi daya nalar seorang hakim dalam menafsirkan dan mempertimbangkan akan norma hukum. Faktor lain yang menyebabkan tinggi rendahnya kualitas putusan hakim ialah ideology yang dianut oleh hakim. Hal ini dikarenakan ideology yang dianut oleh seorang hakim akan mempengaruhi dan mewarnai putusan hakim dalam memutuskan suatu perkara.

Dalam memutuskan suatu perkara, hakim harus mempertimbangkan nilai hukum dan keadilan.Selain itu juga hakim dalam memutuskan suatu perkara harus memperhatikan asas kepastian hukm dan aspek sosiologis. Nilai hukum dikatakan sesuai dengan putusan hakim jika putusan yang mana kita ketahui bahwa putusan merupakan hasil kesimpulan dari semua peristiwa dan fakta yang terjadi dan didapatkan di dalam persidangan dan pemeriksaan itu sejalan dengan norma hukum yang berlaku.Dikaitkan juga dengan keadilan maka suatu putusan hakim berwarna relevan dengan hukum dan berkeadilan. Selain itu, putusan hakim harus memperhatiak nilai guna bagi masyarakat dan juga harus ditegakkan sesuai asas kepastian hukum, dimana kita tahu slogan dalam hukum bahwa hukum harus ditegakkan walaupun langit runtuh dan bumi ini hancur.

Tujuan dalam penegakan hukum melalui putusan hakim adalah tegaknya keadilan.Negara Indonesia, keadilan itu di dasarkan dengan Ketuhana Yang Maha Esa. Oleh karena itu, hakim dalam memutuskan hukum harus berani 
dalam menafsirkan, menyampingkan kepentingan lain guna tegaknya keadilan, keras dan lembutnya hukum guna di dapatnya hukum yang adil. Bagaimana pun keadilan yang seadil adilnya hanya milik tuhan dan putusan hakim tidak luput dari kesalahan.Karena hukum hanya sarana dalam menegakkan keadilan, maka diperlukan sikap dari seorang hakim yang telah disebutkan tadi.Kebebasan dan kemerdekaan hakim terhadap putusan yang dibuatnya merupakan upaya dalam menegakkan keadilan.

Sebelum penulis paparkan tentang pemeriksaan hakim yang mempunyai kemerdekaan dan kemandirian serta kebebasan dalam suatu perkara tindak pidana khususnya Korupsi Pembangunan Embung Di Desa Sungai Abang Kecamatan VII Koto Kabupaten Tebo, perkara Nomor: 29/Pid.Sus.TPK/2016/PN.Jmb, penulis pemaparkan terlebih dahulu dakwaa jaksa penuntut umum seperti di bahwa ini :

1 Menyatakan terdakwa di dakwa oleh tuntutan jaksa telahdibuktikan pada persidangan bahwa yang di dakwa terbukti bersalah perbuatan korupsi dengan bersama-sama sebagaimana di dakwakan dakwaan primair melanggar pasal 2 ayat (1) Jo pasal 18 pasal 18 Undang-undang No 31 Tahun 1999 tentang pemberantasan tindak pidana korupsi Jo Undang-undang No 20 tahun 2001 tentang perubahan atas Undang-undang No 31 tahun 1999 tentang pemberantasan tindak pidana korupsi pasal 3 Undang-undang No 31 Tahun 1999 tentang pemberantasan tindak pidana korupsi.

2 Menyatakan terdakwa oleh penuntut umum, telah didakwa melaksakan perbuatan korupsi bersama-sama sebagaimana di dakwakan dakwaan subsidair telah mengingkari atau melanggar pasal 3 Jo pasal 18 pasal 18 Undang-undang No: 31 Tahun 1999 tentang pemberantasan tindak pidana korupsi Jo Undang-undang No : 20 tahun 2001 tentang perubahan atas Undang-undang No : 31 tahun 1999 tentang pemberantasan tindak pidana korupsi.

3 Memutuskan pidana kepada pelaku atau terdakwa dengan pidana penjara 3 (tiga) tahun penjara dikurangi selama pelaku atau terdakwa menetap dalam tahanan dengan perintah supaya pelaku terus di tahan dan dengan denda sebesar Rp 50.000.000

4 Menjatuhkan uang penganti sebesar Rp. 552.038414.9

Terhadap adanya sikap yang bebas dan merdeka bagi hakim untuk pemeriksaam dan memutuskan suatu perkara seperti dalam putusan hakim pada kasus korupsi embung pada desa sungai abang Kecamatan VII Koto Kabupaten Tebo, perkara Nomor: 29/Pid.Sus.TPK/2016/PN.Jmb, atas nama Ir. Jonatan Nasir Als Jonet Bin Ahmad Nasir fakta dan alat bukti yang di hadapkan dalam persidangan akan di pertimbangkan oleh majelis hakim apakah yang di dakwa melakukan kejahatan terbukti atau tidak. Dalam mempertimbangkan tersebut, ada beberapa hal yang menjadi pertimbangan. Adapun pertimbangan yang menjadi pertimbangan dalam kasus perkara ini adalah:

1. Telah mendengar tuntutan pidana dari JPU yang dibacakan dipersidangan.

2. Nota Pembelaan (Pledoi) terdakwa melalui Penasehat Hukumnya secara tertulis yang dibacakan dipersidangan

3. Replik dari Pennuntut Umumm

4. Duplik terdakwa melalui Penasehat Hukumnya

5. Keterangan saksi. Alat bukti

6. Berdasarkan keterangan saksi, terdakwan dan juga barang bukti, maka diperoleh fakta-fakta hukum yang terungkap.

7. Perbuatan terdakwa telah memenuhi unsur "melakukan kejahatan korupsi dengan cara bersama-sama".

8. Dalam menjatuhkan hukuman pada pelaku dilihat dari faktor terdakwa memiliki kemampuan untuk mempertanggung jawabkan perbuatannya

9. Tidak menemukan adanya sebab pembenaran ataupun sebab pengampunan dalam diri terdakwa

10. Oleh karena perbuatan terdakwa telah memenuhi baik unsur perbuatan pidana maupun unsur pertanggungjawaban pidana

11.Penjatuhan putusan ini adalah dalam rangka mewujudkan keadilan sekaligus memberikan perlindungan masyarakat secara umum dan juga terdakwa

Karena konsekuensi dari seseroang yang terbukti bersalah di pengadilan sama hal nya dengan pelaku korpusi ini, sehingga pelaku perlu di pidana penjara dari dakwaan tersebut dan ongkos perkara dibebankan pada terdakwa.

Memperhatikan pasal 3 Jo pasal 18 pasal 18 Undang-undang No: 31 Tahun 1999 tentang pemberantasan tindak pidana korupsi Jo Undang-undang No: 20 tahun 2001 tentang perubahan atas Undang-undang No: 31 tahun 1999 tentang pemberantasan tindak pidana korupsi dan Undang-undang No: 8 tahun 1981 tentang hukum acara pidana serta peraturan perundang-undangan yang bersangkutan. 
Muhammad Badri dan Bambang Harianto, Studi Putusan Hakim Nomor: 29/Pid.Sus/TPK/2018/PN.Jmb terhadap Pelaku Tindak Pidana Korupsi Pembangunan Embung di Desa Sungai Abang Kecamatan VII Koto Kabupaten Tebo Tahun 2015

\section{Mengadili}

Hakim dalam mengadili terhadap terdakwa Ir. Jonaita Nasir Als Jonet Bin Ahmad Nasir menyatakan bahwa terdakwa tidak terbukti secara sah bersalah melakukan perbuatan korupsi sebagaimana dakwaan primair penuntut umum

1. Membebaskan terdakwa oleh karena itu dari dakwaan primair tersebut

2. Menyatakan terdakwa Ir. Jonaita Nasir Als Jonet Bin Ahmad Nasir terbukti dan dengan kenyakinan bersalah melaksanakan perbuatan korupsi sebagaimana dakwaan subsidair penuntut umum

3. Menyatukan pidana kepada terdakwa Ir. Jonaita Nasir Als Jonet Bin Ahmad Nasir di penjara pidana sebanyak 2 (dua) tahun dan denda sejumlah Rp. 50.000.000

4. Menghukum terdakwa Ir. Jonaita Nasir Als Jonet Bin Ahmad Nasir untuk membayar uang penganti sebesar Rp.335.3888.145.41 ( tiga ratus tiga puluh lima juta tiga ratus delapan puluh delapan ribu empat ratus lima belas rupiah empat puluh sen)

Dalam hal putusan hakim dalam perkara tindak pidana korupsi Pembangunan Embung Di Desa Sungai Abang Kecamatan VII Koto Kabupaten Tebo yaitu adalah suatu keadilan pada suatu perkara telah ditegakkan.korupsi. Pembangunan Embung Di Desa Sungai Abang Kecamatan VII Koto Kabupaten Tebo, dinamakan juga penegakan pidana metariil.Proses beracara dalam persidangan merupakan penegakan keadilan bagi pencari keadilan dalam peradilan dimana peradilan merupakan pelaksana kekuasaan kehakiman, yang memberikan keadilan bagi yang mencari keadilan. Dalam menegakkan keadilan harus mempertimbang dan memperhatikan keadilan kesamaan hukum yang bagian dari penegakan hukum melalui undang-undang atau penegakan hukum pidana metariil.Oleh karena itu, hakim merupakan pemberi keadilan bagi siapa saja yang mencari keadilan.

Dalam hal putusan tersebut di atas menurut hemat penulis putusan yang dijatuhkan hakim kepada kedua terdakwa dalam perkara tindak pidana korupsi Pembangunan Embung Di Desa Sungai Abang Kecamatan VII Koto Kabupaten Tebo tersebut diatas adalah jauh lebih rendah dari hukuman maksimal yang telah ditetapkan undangundang serta dan merugikan Negara dan putusan hakim dalam memberikan putusan denngan menetapkan 2 tahun penjara dengan denda lima puluh juta rupiah (tambah kurungan 3 bulan bila tidak di bayar) dan uang sebagai pengganti dari kerugian atas Negara Rp. Rp. 353.338.415,41 (diganti kurungan 1 tahun bila tidak di bayar 1 bulan sejak putusan hakim), putusan terkait denda dan uang penggati kerugian Negara nilainya sama besar dengan yang di jatuhkan kepada terdakwa an. Faisal Utama, yang notabene terdakwa Faisal Utama hanya merupakan boneka dan suruhan dari terdakwa Ir. Jonaita Nasir Als Jonet dan hanya menerima uang gaji bulanan, sedangkan terdakwa Ir. Jonaita Nasir Als Jonet adalah sebagai otak pelaku (darder) yang bertindak selaku pengendali setiap item kegiatan baik teknis maupun non teknis dan keuangan proyek tersebut, dan yang bermanufer dengan kadis pertanian dan menikmati ung hasil proyek.

Dari uraian tersebut di atas menurut hemat penulis hakim memutuskan kasus ini yang berada di Kecamatan VII Koto Kabupaten Tebo tersebut tidak memenuhi rasa keadilan karena Hakim dalam meraih keadilan merupakan ujung tombak dan seharusnya memiliki peranan penting yang dimiliki hakim untuk menemukan kebenaran dari suatu perkara yang ditanganinya. Dan kebenaran yuridis (hukum), kebenaran filosofis (keadilan) dan sosiologis (kemasyarakatan) harus dipertimbangkan oleh hakim perkara yang di putusnya. Keputusan yang adil lagi bijaksana harus dibuat oleh seorangHakimdengan mempertimbangkan dampak hukum dan dampak yang akan terjadi pada masyarakat termasuk dalam memutus perkara tindak pidana Pembangunan Embung Di Desa Sungai Abang Kecamatan VII Koto Kabupaten Tebo tersebut.

\section{Dasar Pertimbangan Hukum Hakim Terhadap Ringannya Putusan DalamMenjatuhkanPidanaBagi Pelaku Tindak Pidana Korupsi Pembangunan Embung Di Desa Sungai Abang Kecamatan VII Koto Kabupaten Tebo Tahun 2015 Perkara N0 29/Pid.Sus-Tpk/2018/Pn.Jmb}

Pertimbangan yang menjadi dasar bagi hakim perkara yang di putuskannya bisa kita gunakan sebagai bahan untuk menganalisis orientasi hakim dalam memutuskan suatu perkara, dalam hal relevan atau tidaknya putusan dengan tujuan pemindanaan yang hendak dicapai.Secara umum bisa dikatakan, jika suatu keputusan sorang hakim bukan berdasarkan orientasi yang benar, yaitu tidak sesuai dengan apa yang menjadi tujuan pemindanaan, aka akan menimbulkan dampak yang tidak baik akan proses pengatasan masalah kejahatan dan manfaat bagi pelaku tidak akan dirasakan adanya.

Menurut Roeslan Saleh, hakim merupakan figure seorang yang peka akan keadaan sekitar, memelihara dan pemelihara kecerdasan moral serta profesionalisme dalam penegakan hukum bagi masayarakat seluruhnya tanpa terkecuali. Hakim yang bebas serta tidak memihak sehingga dapat meluruskan semua yang dirasa oleh terdakwa sepihak,separuh benar dan sikap yang kurang tepat petuga pengadilan ${ }^{9}$

\footnotetext{
${ }^{9}$ Roeslan saleh, Mengadili sebagai Pergulatan Kemanusiaan, Aksara Baru, Jakarta,1983.hal 45
} 
Adapun putusan hakim dalam tindak pidana umumnya berupa sanksi pidana. Sanksi pidana menegaskan atau lebih menekankan kepada hukuman penjaradifokuskan pada tindakan yang di larang oleh hukum terlebih dahulu di lakukan. berdasarkan tujuannya sanksi pidana memberikan penderitaan istimewah atas pelanggar akibat perbuatannya, selain dikenakan hukuman pada pelaku, ini juga sebagai penghinaan bagi pelaku. ${ }^{10}$

Kemudian putusan hakim akan berlaku apabila di sidang terbuka untuk umum diucap dan dikatakan (pasal 195 KUHAP) dan harus di tanda tangani hakim dan panitera seketika putusan selesai diucapkan (pasal 200 KUHAP), kemudian apabila dilihat dari ketentuan KUHAP, dapat disimpulkan bahwa putusan hakim itu hakekatnya dapat dikatagorikan ke dalam dua jenis, yaitu putusan akhir dan putusan yang bukan akhir. Apabila suatu perkara oleh majelis hakim diperiksa sampai selesai pokok perkaranya, hal ini berdasarkan ketentuan pasal 182 ayat 3, pasal 197 dan pasal 199 KUHAP dinamakan putusan akhir atau putusan, pada jenis putusan ini prosedural yang harus dilakukan adalah setelah persidangan dibuka, memeriksa identitas terdakwa dan peringatan agar kondusif di dalam persidangan, pembacaan surat dakwaan, keberatan, pemeriksaan alat bukti, replik dan duplik kemudian re-replik dan re-duplik, pernyataan pemeriksaan ditutup serta musyawarah masjelis hakim dan pembacaan putusan ${ }^{11}$

Putusan hakim memang dituntut oleh masyarakat untuk berlaku adil, tapi hakim tetaplah manusia yang tidak bisa dengan putusannya memuaskan seluruh pihak, walaupun hakim manusia, hakim dituntut bisa menghasilkan suatu keputusan yang seadil-adilnya berdasarkan fakta-fakta di persidangan sesuai hukm dan hati nurani.

Dalam kasus tindak pidana Korupsi Pembangunan Embung Di Desa Sungai Abang Kecamatan VII Koto Kabupaten Tebo Tahun 2015, banyak faktor yang dijadikan sebagai pertimbangan hakim memutus ringanya putusan apabila kurangnya terbukti melakukan tindak pidana dan tidak cukup bukti maupun menetukan ringan berat penjatuhan hukuman bagi pelaku Korupsi Pembangunan Embung Di Desa Sungai Abang Kecamatan VII Koto Kabupaten Tebo. Pasal 3 Jo pasal 18 Undang-undang No: 31 Tahun 1999 tentang pemberantasan tindak pidana korupsi Jo Undang-undang No: 20 tahun 2001 tentang perubahan atas Undang-undang No: 31 tahun 1999 tentang pemberantasan tindak pidana korupsi, pasal 3 Undang-undang No: 31 Tahun 1999 tentang pemberantasan tindak pidana korupsi berbunyi:

Di pidana penjara sesingkat-singkatnya 1 tahun dan selama-lamanya 20 tahun dan dengan ganit rugi sebesar Rp 50.000.000.00 ini semua apabila seseorang melakukan perbuatan yang melawan hukum dengan menyelewengkan wewenang, peluang serta dengan kedudukannya sebagai pejabat atau atasan sehingga yang dapat merugikan keuangan Negara atau perekonomian Negara hal ini bermaksud dengan sengaja mengambil guna untuk menguntungkan diri sendiri.

Kemudian pasal 18 Undang-undang No: 31 tahun 1999 tentang pemberantasan tindak pidana korupsi berbunyi:

1) Selain pidana tambahan sebagaimana dimaksud dalam Kitab Undang-Undang Hukum Pidana, sebagai pidana tambahan adalah :

a Perampasan barang bergerak yang berwujud atau yang tidak berwujud atau barang tidak bergerak yang digunakan untuk atau yang diperoleh dari tindak pidana korupsi, termasuk perusahaan milik terpidana di mana tindak pidana korupsi dilakukan, begitu pula dari barang yang menggantikan barang-barang tersebut

b Pembayaran uang pengganti yang jumlahnya sebanyak-banyaknya sama dengan harta benda yang diperoleh dari tindak pidana korupsi

c Penutupan seluruh atau sebagian perusahaan untuk waktu paling lama 1 (satu) tahun

d Pencabutan seluruh atau sebagian hak-hak tertentu atau penghapusan seluruh atau sebagian keuntungan tertentu, yang telah atau dapat diberikan oleh Pemerintah kepada terpidana.

2) Jika terpidana tidak membayar uang pengganti sebagaimana dimaksud dalam ayat (1) huruf b paling lama dalam waktu 1 (satu) bulan sesudah putusan pengadilan yang telah memperoleh kekuatan hukum tetap, maka harta bendanya dapat disita oleh jaksa dan dilelang untuk menutupi uang pengganti tersebut.

3) Dalam hal terpidana tidak mempunyai harta benda yang mencukupi untuk membayar uang pengganti sebagaimana dimaksud dalam ayat (1) huruf b, maka dipidana dengan pidana penjara yang lamanya tidak melebihi ancaman maksimum dari pidana pokoknya sesuai dengan ketentuan dalam Undang-undang ini dan lamanya pidana tersebut sudah ditentukan dalam putusan pengadilan.

Adapun kronologis terjadinya suatu tindak Pidana Korupsi Pembangunan Embung Di Desa Sungai Abang Kecamatan VII Koto Kabupaten Tebo Tahun 2015 dengan Nomor perkara : 29/Pid.Sus.TPK/2016/PN.Jmb, atas nama Ir. Jonatan Nasir Als Jonet Bin Ahmad Nasir pada pokoknya telah melakukan telah melakukam tindak pidana korupsi Pembangunan Embung Di Desa Sungai Abang Kecamatan VII Koto Kabupaten Tebo.

${ }^{10}$ Sholehuddin, Sistem Sanksi Dalam Hukum Pidana, Ide Dasar Double Track Sistem Inplementasinya, Rajawi Pers, Jakarta, 2003, hal 17-18

${ }^{11}$ Lilik Mulyadi, Bunga Rampai Hukum Pidana Perfektif Teoritis dan Praktis, Edisi Pertama, Alumni, Bandung, 2008, halaman 129-130 
Berdasarkan kronologis tersebut diatas perkara Nomor : 29/Pid.Sus.TPK/2016/PN.Jmb dalam menjatuhkan pidana kasus korupsi setelah menimbang bahwa tindak pidana korupsi Pembangunan Embung Di Desa Sungai Abang Kecamatan VII Koto Kabupaten Tebo penuntutan umum yang menuntut agar di hukum pidana penjara selama 3 (tiga) tahun dan denda sebesar Rp. 50.000.000 subsider 6 (enam) bulan kurungan dan menjatuhkan pidana tambahan membayar uang penganti sebesar Rp. 552.038.414.9, majelis hakim berpendapat bahwa pertimbangan dengan memperhatikan, keterangan yang didapat dari alat bukti, saksi dan terdakwa, sehingga dengan itu hakim menjatuhkan hukuman dengan hukuman yang berat atau tidaknya, juga mempertimbangkan putusan yang mengandung edukatif atau pembelajaran akan dari kesalahan yang di buat terdakwa, menimbang uttuk penjatuhan pidana di perlukan pertimbangan akan keadaan yang bisa memberatkan dan juga yang meringankan.

a. Hal-hal yang memberatkan: Terdakwa tidak membantu program pemerintah memberantas korupsi.

b. Hal-hal yang meringankan: Terdakwa berlaku sopan di persidangan dan terdakwa belum pernah di hukum dalam perkara ini.

Sehingga majelis hakim memutus perkara tindak pidana korupsi Pembangunan Embung Di Desa Sungai Abang Kecamatan VII Koto Kabupaten Tebo terdakwa Ir. Jonatan Nasir Als Jonet Bin Ahmad Nasir di putus oleh hakim dengan hukuman 2 tahun pidana kurungan dengan denda Rp 50.000.000.

Adapun bahan pertimbangan hakim penjatuhan pidana korupsi Pembangunan Embung Di Desa Sungai Abang Kecamatan VII Koto Kabupaten Tebo perkara Nomor: 29/Pid.Sus.TPK/2016/PN.Jmb pada pokoknya adalah sebagai berikut: berlandasan dengan bukti yang telah di ungkap oleh majelis hakim di pengadilan disebutkan, hakim Majelis memberikan pertimbangan apakah unsur unsur pidana dari perbuatan terdakwa tersebut di dakwakan oleh Penuntut Umum tersebut sebagai tindak pidana yang mana telah terpenuhi.

Terdakwa diajukan ke persidangan oleh penuntut umum dengan dakwaan yang bersifat alternative yakni :

Kesatu: secara sah telah bersalah melaksanakan suatu perbuatan korupsi dengan bersama-sama sebagai di dakwa dalam dakwaan primer melanggar pasal 2 ayat (1) Jo pasal 18 Undang-undang No: 31 Tahun 1999 tentang pemberantasan tindak pidana korupsi Jo Undang-undang No: 20 tahun 2001 tentang perubahan atas Undang-undang No: 31 tahun 1999 tentang pemberantasan tindak pidana korupsi.

Kedua: secara sah telah bersalah melaksanakan suatu perbuatan korupsi dengan bersama-sama sebagai di dakwa dalam dakwaan primer melanggar pasal 3 Jo psl 18 Undang-undang No: 31 Tahun 1999 tentang pemberantasan tindak pidana korupsi Jo Undang-undang No: 20 tahun 2001 tentang perubahan atas Undang-undang No: 31 tahun 1999 tentang pemberantasan tindak pidana korupsi. Berdasarkan dakwaan yang alternative sehingga hakim bebas guna menentukan dakwaan secara langsung suatu pertimbangan hakim dapat di dasarkan kenyataan hukum sebagaimana di tampilkanpada saat persidangan berlangsung.

Atas dasar kenyataan tersingkap pada saat di persidangan sehingga hakim memutuskan untuk mempertimbangkan dakwaan Kesatu: secara sah dan teryakin bersalah melakukan korupsi degan cara bersama-sama sebagai di dakwa dalam dakwaan subside melanggar psl 3 Jo pasal 18 Undang-undang No: 31 Tahun 1999 tentang pemberantasan tindak pidana korupsi Jo Undang-undang No: 20 tahun 2001 tentang perubahan atas Undang-undang No: 31 tahun 1999 tentang pemberantasan tindak pidana korupsi.

Putusan tindak pidana korupsi Pembangunan Embung Di Desa Sungai Abang Kecamatan VII Koto Kabupaten Tebo perkara Nomor: 29/Pid.Sus.TPK/2016/PN.Jmb, dasar yang menjadi penjatuhan pidana korupsi sesuai pasal 3 ayat Undang-undang No: 20 tahun 2001 jo Undang-undang No 31 tahun 1999 yaitu yuridis dan juga non yuridis. Yang dijelaskan: yuridis merupakan dasar dari hakim mempertimbangkan hukuman berdasarkan hukum. Pertimbangan yang teliti dan cermat dalam memeriksa dengan apa yang terdapat dalam persidangan, yang memenuhi unsur korupsi yaitu:

1. Memberikan keuntungan untuk diri sendiri, orang ain ataupun koorporasi

2. Penyalahgunaan kewanangan sarana atau kesempatan yang tersedia karena kedudukan atau jabatan

3. Membuat kerugian bagi Negara

Sedangkan non yuridis tadi adalah dasar yang dilihat dari luar hukum.seperti pertimbangan motivasi yang menjadi sebab dilakukannya kejahatan serta akibat yang timul guna memutuskan berat ringannya hukuman. Juga memperhatikan hal-hal yang dapat memberatkan juga meringankan bagi pelaku seperti sifat baik ataupun jahat yang ada pada terdakwa sebagaimana bunyi pada undang-undang tentang kekuasaan kehakiman pada pasal 8 ayat 2 Undang-undang No 48 Tahun 2009 yaitu "Dalam mempertimbangkan berat ringannya, hakim wajib memperhatikan pula sifat yang baik dan jahat dari terdakwa".

Ringanya putusan hakim tindak pidana korupsi Pembangunan Embung Di Desa Sungai Abang Kecamatan VII Koto Kabupaten Tebo perkara Nomor : 29/Pid.Sus.TPK/2016/PN.Jmb, menurut hemat penulis hakim memutus perkara ini dengan satu pasal yaitu dakwaa subsider pasal 3 Undang-undang No 20 tahun 2001 jo Undang-undang No 
31 tahun 1999 tentang pemberantasan tindak pidana korupsi, namun hakim membebaskan terdakwa dari dakwaan primair yaitu pasal 2 ayat (1) Undang-undang No 20 tahun 2001 jo Undang-undang No 31 tahun 1999 tentang pemberantasan tindak pidana korupsi, sehingga hakim penjatuhkan hukuman kurungan penjara 2 tahun serta denda Lima Puluh Juta Rupiah / Rp 50.000.000

\section{SIMPULAN}

1. Apakah Putusan Hakim N0 29/Pid.Sus-Tpk/2018/Pn.Jmb Terhadap Pelaku Tindak Pidana Korupsi Pembangunan Embung Di Desa Sungai Abang Kecamatan VII Koto Kabupaten Tebo Tahun 2015 Telah Memenuhi Keadilan. Dalam hal putusan tersebut bahwa putusan hakim belum memenuhi rasa keadilan karena putusan tersebut baik itu hukumannya tidak sesuai dengan perbuatan pelaku seperti di penjara selama 2 tahun serta uang penganti kerugian Negara yang sama dengan terdakwa lainnya sedang terdakwa Ir. Jonatan Nasir Als Jonet Bin Ahmad Nasir merupakan otak pelaku (dader)

2. Dasar yang menjadi pertimbangan hukum bagi hakim Terhadap Ringannya Putusan atas tindak pidana korupsi Pembangunan Embung yang terjadi di Desa Sungai Abang Kecamatan VII Koto Kabupaten Tebo Tahun 2015 Perkara N0 29/Pid.Sus-Tpk/2018/Pn.Jmb. karena hakim memutus perkara ini dengan satu pasal yaitu dakwaa subsider pasal 3 Undang-undang No 20 tahun 2001 jo Undang-undang No 31 tahun 1999 tentang pemberantasan tindak pidana korupsi, namun hakim membebaskan terdakwa dari dakwaan primair yaitu pasal 2 ayat (1) Undangundang No 20 tahun 2001 jo Undang-undang No 31 tahun 1999 tentang pemberantasan tindak pidana korupsi

\section{DAFTAR PUSTAKA}

\section{Buku}

Nanda Agung Dewantara, Masalah Kebebasan Hakim Dalam Menangani Suatu Perkara Pidana, Jakarta, Aksara Persada Indonesia, 1987,

Sudarto, Kapita Selekta Hukum Pidana, Bandung, Alumni, 1986.

Muladi dan Barda Nawawi Arief, Bunga Rampai Hukum Pidana, Bandung, Alumni, 1992,

Roeslan saleh, Mengadili sebagai Pergulatan Kemanusiaan, Aksara Baru, Jakarta,1983.

Sholehuddin, Sistem Sanksi Dalam Hukum Pidana, Ide Dasar Double Track Sistem Inplementasinya, Rajawi Pers, Jakarta, 2003,

\section{Peraturan Perundang-undangan}

Kitab Undang-undang Hukum Acara Pidana

Undang-undang Nomor 20 Tahun 2001 Tentang Perubahan Atas Undang-undang Nomor 31 Tahun 1999 Tentang Pemberantasan Tindak Pidana Korupsi

Undang-undang Nomor 48 Tahun 2009 Tentang Kekuasaan Kehakiman 